This item was submitted to Loughborough's Research Repository by the author.

Items in Figshare are protected by copyright, with all rights reserved, unless otherwise indicated.

\title{
Sharing values to safeguard the future: British Holocaust Memorial Day commemoration as epideictic rhetoric
}

\section{PLEASE CITE THE PUBLISHED VERSION}

https://doi.org/10.1177/1750481317745743

\section{PUBLISHER}

SAGE $@$ The Author

VERSION

AM (Accepted Manuscript)

\section{PUBLISHER STATEMENT}

This work is made available according to the conditions of the Creative Commons Attribution-NonCommercialNoDerivatives 4.0 International (CC BY-NC-ND 4.0) licence. Full details of this licence are available at: https://creativecommons.org/licenses/by-nc-nd/4.0/

\section{LICENCE}

CC BY-NC-ND 4.0

\section{REPOSITORY RECORD}

Richardson, John E.. 2019. "Sharing Values to Safeguard the Future: British Holocaust Memorial Day Commemoration as Epideictic Rhetoric". figshare. https://hdl.handle.net/2134/26604. 


\section{Sharing values to safeguard the future: British Holocaust Memorial Day Commemoration as Epideictic rhetoric}

John E. Richardson, Loughborough University

John E. Richardson

Department of Social Sciences,

Loughborough University

Epinal Way,

Loughborough, Leicestershire,

LE11 3TU, UK

j.e.richardson@lboro.ac.uk

$+44(0) 1509223361$

Biog

John E Richardson is a Reader in Critical Discourse Studies, Department of Social Sciences, Loughborough University. His research interests include structured social inequalities, British fascism, argumentation and multimodal commemoration. His most recent book is British Fascism: A Discourse-Historic Analysis (Stuttgart: ibidem Verlag, 2017). He is Editor of the international journal Critical Discourse Studies and co-editor of Bloomsbury book series Advances in Critical Discourse Studies. From February 2017-January 2018 he was a Leverhulme Trust Research Fellow, researching the ways that Holocaust Memorial Day in the UK has changed since 2002. 


\title{
Sharing values to safeguard the future: British Holocaust Memorial Day Commemoration as Epideictic rhetoric
}

\begin{abstract}
This article explores the rhetoric, and mass-mediation, of the national Holocaust Memorial Day (HMD) commemoration ceremony, as broadcast on British television. I argue that the televised national ceremonies should be approached as an example of multi-genre epideictic rhetoric, working up meanings through a hybrid combination of genres (speeches, poems, readings), author/animators and modes (speech, music, light, movement and silence). Epideictic rhetoric has often been depreciated as simply ceremonial "praise or blame” speeches. However, given that the topics of praise/blame assume the existence of social norms, epideictic also acts to presuppose and evoke common values in general, and a collective recognition of shared social responsibilities in particular. My methodology draws on the Discourse-Historical Approach to Critical Discourse Analysis, given, first, its central prominence on analysing argumentative strategies in discourse and, second, the ways it facilitates a reflexive 'shuttling' between text-discursive features, intertextual relations, and wider contexts of society and history. Here, I examine how a catastrophic past is invoked in speech and evoked through image and music, in response to the demands that uncertainty of the future “places upon one’s conscience” (Lauer 2015:12).
\end{abstract}

\section{Keywords}

Rhetoric, Epideictic, Commemoration, Holocaust Memorial Day, Discourse-Historic Analysis, Multi-modality 


\section{Introduction}

Since 2001, Britain has commemorated the victims of the Holocaust and subsequent genocides on 27 January - the day that Auschwitz-Birkenau was liberated by the Red Army. The decision to initiate a transnational Holocaust Remembrance Day was taken in the Stockholm International Forum in 2000, at the end of which representatives from 46 governments around the world signed a declaration committing to preserve the memory of those who have been murdered in the Holocaust (Allwork 2015). On 1 November 2005, the UN General Assembly adopted Resolution 60/7, which resolved "that the United Nations will designate 27 January as an annual International Day of Commemoration in memory of the victims of the Holocaust", and requested "a programme of outreach [and] measures to mobilize civil society for Holocaust remembrance and education”. ${ }^{1}$

The aim of the British Holocaust Memorial Day (HMD), stated from the outset, is "to move from the past to the present, from the particular to the universal. The stories of individuals and families will be used so that the fate of the Jews and other 'targets' of Nazi racialbiological politics can be personalized and the catastrophe perceived as a human event” (Cesarani, 2000: 63). The content of the official HMD ceremony was controlled by the government until 2005, when responsibility passed to the Holocaust Memorial Day Trust (HMDT). As Whyborn (2011) - the-then Chief Executive of the HMDT - put it, HMD "provides everyone with the opportunity to remember the victims of the Holocaust, Nazi persecution and subsequent genocides and to honour the survivors of those atrocities” (p.57). All national Holocaust commemoration is directed towards taking 'lessons' from genocide; it is aimed, above all, “as an educational event” (Cesarani 2001: 40) and exists primarily for didactic purposes.

British awareness and understanding of the Holocaust - what Pearce (2014) calls Holocaust consciousness - has developed hand in hand with its mass mediation, whether through 
fictional or actuality genres (Kansteiner 2006, 2008; Meyers et al 2014; Shandler 1999). British television and radio broadcast a variety of programmes to mark the day, though the form and frequency of this mass mediation commemoration has been uneven. The first British HMD ceremony, in 2001, was held in Westminster Central Hall and televised live on the BBC to around 1.5 million viewers (see Macdonald 2005; Pearce 2013; Sauer 2012). A capacity audience of 2,000 were present in the Hall, including leaders of the three main political parties, cultural figures, 200 Holocaust survivors and representatives of the wider Jewish communities; Prime Minister Tony Blair gave the keynote speech. Since then, the national ceremony has been broadcast four further times: in 2002 on Regional Independent Television, and on BBC2 in 2005, 2015 and 2016.

National HMD commemoration in Britain communicates an understanding of the Holocaust as a catastrophe and a great affront to Our values; detailing the circumstances and consequences of the Holocaust acts to revivify Our commitment to the values that it so clearly transgressed. These values are invoked linguistically and evoked through other modes - principally images and music. This article analyses the rhetoric, and mass-mediation, of the national Holocaust Memorial Day (HMD) commemoration ceremony, as broadcast on British television, and specifically focuses on the ways that it communicates social values. Given that the Holocaust has become a fixture of Western culture (Cole 2000; Marrus 2015), my findings have relevance beyond British commemoration of the Holocaust.

\section{Literature Review}

Rhetorical arguments, schemes and tropes are utilised in commemoration as part of pedagogic - and persuasive - strategies, aimed at achieving communion between various institutionalised "memory makers” and "memory consumers” (Kansteiner 2002). Since 
Aristotle, "Rhetoric may be defined as the faculty of observing in any given case the available means of persuasion” (Rhetoric 1355b 27-28). As such, Aristotle’s Rhetoric “provides a method for looking at rhetoric as a human phenomenon, for learning how to use it, and also for a system of criticism” (Kennedy 2005: 20).

Aristotle identified three species of rhetorical discourse: deliberative/political rhetoric; forensic/legal rhetoric; and epideictic/ceremonial rhetoric. Each of these three species of persuasive discourse have specific rhetorical goals and hence tend to adopt special topics in articulating (and, ideally, in fulfilling) such goals. Epideictic or ceremonial rhetoric is directed towards proving someone or something worthy of admiration or disapproval; it is concerned with the present, its means are praise and censure and its special topics are honour and dishonour. In more detail, Aristotle’s Rhetoric codified epideictic "primarily as a written genre (3.12) delivered before an audience of spectators (1.3), which praises or blames a subject (1.3), relates this topic to the present time (1.9), and achieves its rhetorical force (dynamis) through ethos (1.9), amplification (3.17), and narrative (3.16)” (Lauer 2015: 5). The three species of rhetoric are heuristics, of course, that seldom occur in everyday argumentation in a pure form (Richardson 2007; Wodak \& De Cillia 2007). Commemoration represents a blended rhetorical genre that brings together the epideictic and forensic species of rhetorical argument, operates through a combination of praise/censure and accusation/defence, and draws on the special topics of (dis)honour and (in)justice. In such discourse, the language of values and praise typical of epideictic rhetoric is blended with narrative accounts of the past and the language of (self)identification, deictically fixed to the here and now (Billig \& Marinho 2017; Slavíčková 2013, 2014). They “retrive the past for the present” (Wodak \& De Cillia 2007: 346), the ideal rhetorical consequence of which is that 'we' associate ourselves with the praised actors and actions of the past and disassociate ourselves from those criticised. 
Epideictic rhetoric has, in the past, been depreciated as ceremonial "praise or blame” speeches which simply trade on commonplace knowledge. As such, epideictic tends to be the Aristotelian species of rhetoric that attracts the least critical attention from scholars (though see Billig \& Marinho 2017). A great deal of this may be attributable to Aristotle’s own failure to "formulate its role in the instilling, preservation, or enhancement of cultural values, even though this was clearly a major function” (Kennedy 2005: 22). Epideictic does invoke praise and blame. However, given that the rhetorical strategies of praise or blame assume the existence of social norms, upon which this praise or blame is based, epideictic also acts to presuppose and evoke common values - and, implicitly, a collective recognition of shared social responsibilities to uphold these values (Kampf \& Katriel 2016). On this point, Duffy (1983: 85) argues that the purpose of epideictic oratory is to "represent, however imperfectly, timeless values distilled from past experiences”. Such values are invoked for educative and ethical reasons (Burgess 1902; Kampf \& Katriel 2016; Perelman 1982; Pernot, 2015; Rosenfield 1980). For Hyde (2005a: 11), epideictic acts as “a collective or public form of recognition, a pragmatic and 'moral act' that supplies meaning to life; it facilitates social awareness and understanding to recognize and understand difference.” Perelman and Olbrechts-Tyteca (1969: 50) go as far as to argue that “epideictic oratory has significance and importance for argumentation because it strengthens the disposition toward action by increasing adherence to the values it lauds.” Similarly, Vatnoey (2015: 1) suggests that epideictic "has the potential to strengthen the common values in society, create community, and form the beliefs that determine future decision-making.” Thus, whilst epideictic "generally features colourful style, praise and blame, non-controversiality, universal values, and prominent leaders and speakers. Each of these characteristics arises because it serves optimally the function of communal definition” (Condit 1985: 291). 
Epideictic rhetoric is therefore one way in which what Elder-Vass (2010, 2011, 2012, 2015) calls “norm circles” are discursively invoked, shaped and shared. Norm circles are "groups of people who are committed to endorsing and enforcing specific norms” (Elder-Vass 2012: 201-202). More specifically, Elder-Vass (2012: 22-23) argues that norm circles “are social entities with people as their parts, and because of the ways in which the members of such groups interact (a mechanism) they have the causal power to produce a tendency in individuals to follow standardised practices”. Causal powers “operate as tendencies. Any given causal power has a tendency to produce a certain sort of outcome but these tendencies may be frustrated when causal powers with conflicting tendencies interact with them” (ElderVass 2012: 16). Epideictic rhetoric works against this erosion of values, acting to bolster the causal power of the norm circle by revivifying its commitment to a shared norm. The epideictic orator is someone who "by speaking wishes to strengthen established values", which "may be likened to the guardian of dykes under constant assault by the ocean” (Perelman \& Olbrects-Tyteca 1969: 55). As Lauer (2015: 12) puts it, "With an awareness that the future is always not yet present, epideictic responds to the demands that such uncertainty places upon one's conscience.” This uncertainty provokes what Hyde (2005b: 7) refers to as "the call of conscience," understood as an appeal founded on "the related issues of right and wrong, the good and the bad, the just and the unjust, the truth and the untruth” (see also Butler 1995).

Tileagă (2011: 197) argues that in certain social contexts - e.g. where there are hegemonic understandings of victim, perpetrator and bystander roles - "biography, memory, and identity are managed and displayed” rather than invoked as part of explicit persuasive strategies. However, just because such materials are documented, rather than being utilised explicitly as part of an argument, doesn't mean that they're not being used rhetorically. Aristotle referred to such strategies as non-artistic means of persuasion, since they "do not depend on the 
speaker's skill but are based on using pre-existing material” (van Eemeren et al 1996: 43). Non-artistic means of persuasion amount to other texts (laws, witnesses, photographs, etc.) that the speaker calls upon and uses, so does not need to invent. Examples of this in HMD commemoration include iconic photographs, or archival films, which are used as visual reminders of the people being commemorated and the historic events in which they were involved. Artistic means of persuasion are of three types: "through character [ethos] whenever the speech is spoken in such a way as to make the speaker worthy of credence; for we believe fair-minded people to a greater extent and more quickly (Rhetoric 1356a 4); "through the hearers when they are led to feel emotion [pathos] by the speech; for we do not give the same judgment when grieved and rejoicing or when being friendly and hostile” (Rhetoric 1356a 5); and "through the arguments [logos] when we show the truth or the apparent truth from whatever is persuasive” (Rhetoric 1356a 6). The ethetic manoeuvring of the speaker, and their ability to display phronēsis (practical wisdom) and arēte (virtue), is marked as being particularly important to the success of epideictic rhetoric (see Hauser 1999).

Lauer (2015: 8) argues: “Advances in epideictic scholarship require an understanding of the pivotal role that the non-linguistic features of certain rhetorical events play in producing meaning.” In short, epideictic arguments are frequently advocated multi-modally. Groarke (2013: 34) supports his case for “accepting multi-modal arguments” by reasoning that an argument, at base, “is an attempt to support a conclusion by presenting evidence for it something that can clearly be done in ways that extend beyond premises and conclusions understood as declarative sentences.” This is certainly the case when examining complex, multi-modal speech events such as commemorations (Sauer 2012), where music, colour and movement can be used to play with the sentiment and mood of the audience, thereby contributing to an event's pathotic rhetorical strategies. 


\section{Data and Method}

This article is drawn from a wider project aimed at analysing linguistic and semiotic processes employed in the commemoration of HMD, their potential for shaping the understanding of mass audiences and the ways that the commemoration of HMD has changed since 2002. I am particularly interested in the rhetorical use of the past in the construction of political arguments regarding (collective) identity and (shared) values (Forchtner 2016). My methodology draws on Critical Discourse Studies, and more specifically on the Discourse-Historical Approach (Heer et al 2008; Krzyżanowski 2010; Reisigl 2018; Reisigl \& Wodak 2001, 2009; Richardson 2017a; Richardson \& Wodak 2009; Slavíčková 2013, 2014; Wodak \& De Cillia 2007; Wodak et al 1999), in order to make sense of (1) the field of remembrance and its genres (e.g. ceremonies, speeches, stories, testimony, music, minutes of silence, etc.) and (2) the ways that they reflect the complex interplay between collective remembering (Wertsch 2002) and social and historic contexts. The Discourse-Historical Approach (DHA) specifically orientates to argumentation as a discursive strategy in which people may offer, justify, legitimate or criticise standpoints.

As stated above, there are three types of artistic means of persuasion: through character (ethos, utilizing ethetic strategies), through emotion (pathos, utilizing pathotic strategies) and through argument (logos, utilizing logetic strategies). Logetic strategies, or argumentation schemes (and here I depart with Aristotle and draw on contemporary argumentation theory) constructed and/or delivered by the rhetor are of three types: symptomatic argument (arguing from example); comparative argument; and causal argument (Snoeck Henkemans 2002; van Eemeren and Grootendorst 1992). Taking each in turn: symptomatic arguments are based on relations of typicality, symptoms or concomitance. Often in such arguments, an example is used to illustrate a wider pattern or trend - and such arguments can fail due to hasty 
generalization. This fallacy is most closely related to non-artistic means of persuasion, when 'evidence' produced is not symptomatic of the standpoint. Comparison argumentation is based on a relation of analogy. An arguer defends his/her standpoint by showing that what is stated in the argument is similar to that which is stated in the standpoint "and that on the grounds of this resemblance the standpoint should be accepted” (van Eemeren, Grootendorst \& Snoeck Henkemans, 2002: 99). Analogous argumentation fails most frequently due to poor grounds for comparison. Finally, with causal argumentation "the acceptability of the premises is transferred to the conclusion by making it understood that there is a relation of causality between the argument and the standpoint” (van Eemeren \& Grootendorst, 1992: 97). Causal argumentation can fail for a variety of reasons, including causal oversimplification (also called causal reductionism), and classic post hoc ergo propter hoc and slippery slope fallacies.

This article analyses the four national (British) HMD ceremonies broadcast on television since 2001. In 2005, 2015 and 2016 the BBC broadcast the full hour-length ceremony; in 2002, an abbreviated version, edited to 25 minutes, was broadcast on Regional Independent TV (though the ceremony itself was a full hour). These ceremonies feature a combination of film, music, candle lighting, and speeches from celebrities, survivors and public figures. As Macdonald (2005: 62) put it, they are organised not as “a single ritual but a show - a sequential set of pieces" which, in keeping with the aim of HMD, are "more explicitly pedagogical than many memorials”. Table 1, below, presents the content and running order of the 2002 commemoration. 
Table 1: Running order of the 2002 HMD commemoration, as broadcast on ITV

\begin{tabular}{|c|c|c|c|}
\hline Time & Segment & Speaker & Gist \\
\hline $0-1.16$ & $\begin{array}{l}\text { Opening; music } \\
\text { with Voice } \\
\text { Over }\end{array}$ & Unknown & $\begin{array}{l}\text { Provides an abstract for the } \\
\text { programme: introduces the } \\
\text { Holocaust as a historic event \& why } \\
\text { it is commemorated }\end{array}$ \\
\hline $1.17-2.58$ & $\begin{array}{l}\text { Music with } \\
\text { testimony }\end{array}$ & $\begin{array}{l}\text { Two female } \\
\text { Holocaust survivors }\end{array}$ & $\begin{array}{l}\text { Fragments of personal narratives of } \\
\text { oppression; music provides } \\
\text { emotional tenor }\end{array}$ \\
\hline $2.59-4.15$ & $\begin{array}{l}\text { Poem, 'Refugee } \\
\text { Blues' by WH } \\
\text { Auden }\end{array}$ & $\begin{array}{l}\text { Christopher } \\
\text { Eccleston }\end{array}$ & Reading of a poem \\
\hline 4.16-7.08 & $\begin{array}{l}\text { Music with } \\
\text { testimony }\end{array}$ & $\begin{array}{l}\text { Two male and then } \\
\text { one female } \\
\text { Holocaust survivor }\end{array}$ & $\begin{array}{l}\text { Fragments of personal narratives of } \\
\text { oppression and mass murder; music } \\
\text { provides emotional tenor }\end{array}$ \\
\hline 7.09-8.42 & $\begin{array}{l}\text { Reading, } \\
\text { wrongly } \\
\text { captioned 'Elli' } \\
\text { Wiesel }\end{array}$ & Ben Kingsley & $\begin{array}{l}\text { Reading of book extract - incredibly } \\
\text { portentous delivery }\end{array}$ \\
\hline $8.43-11.05$ & Music & - & Music, not identified on screen \\
\hline $\begin{array}{l}11.08- \\
13.15\end{array}$ & $\begin{array}{l}\text { Homily, with } \\
\text { music }\end{array}$ & $\begin{array}{l}\text { Chief Rabbi } \\
\text { Jonathan Sacks }\end{array}$ & $\begin{array}{l}\text { Speech shown in full; music (not } \\
\text { identified) fades in half way through }\end{array}$ \\
\hline $\begin{array}{l}13.16- \\
14.53\end{array}$ & $\begin{array}{l}\text { Poem, } \\
\text { 'Colourblind' } \\
\text { by Lemn Sissay }\end{array}$ & Lemn Sissay & $\begin{array}{l}\text { Poem about (white) people claiming } \\
\text { not to see his (black) colour; critique } \\
\text { of implicit racism in denials of racial } \\
\text { particularism }\end{array}$ \\
\hline $\begin{array}{l}14.54- \\
16.57\end{array}$ & $\begin{array}{l}\text { Music, } \\
\text { combined with } \\
\text { testimony }\end{array}$ & $\begin{array}{l}\text { Three unnamed } \\
\text { speakers, give very } \\
\text { brief points about } \\
\text { persecution and } \\
\text { discrimination }\end{array}$ & $\begin{array}{l}\text { Disabled speaker refers to murder } \\
\text { and forced sterilization of disabled } \\
\text { people under Nazism; gay speaker } \\
\text { gives abbreviated narrative of } \\
\text { prejudice against homosexuals now; } \\
\text { Roma speaker mentions importance } \\
\text { of education }\end{array}$ \\
\hline $\begin{array}{l}16.57- \\
19.05\end{array}$ & Speech & $\begin{array}{l}\text { David Blunkett, } \\
\text { Home Secretary }\end{array}$ & $\begin{array}{l}\text { Speech about Holocaust, its } \\
\text { relevance today (and our requirement } \\
\text { to welcome the stranger); finishes by } \\
\text { suggesting survivors make us } \\
\text { humble }\end{array}$ \\
\hline $\begin{array}{l}19.06- \\
21.30\end{array}$ & Prayer & Cantor & Sung in Hebrew, no subtitles \\
\hline $\begin{array}{l}21.34- \\
22.07\end{array}$ & $\begin{array}{l}\text { Poem, Pastor } \\
\text { Niemoller }\end{array}$ & $\begin{array}{l}\text { Four speakers, } \\
\text { including } \\
\text { Ecclestone \& } \\
\text { Kingsley }\end{array}$ & $\begin{array}{l}\text { Abbreviated version of the poem } \\
\text { (refers to Communists, Trade } \\
\text { Unionists, Jews, and 'no one left to } \\
\text { speak for me') }\end{array}$ \\
\hline $\begin{array}{l}22.08- \\
24.00\end{array}$ & $\begin{array}{l}\text { Song, } \\
\text { 'Something } \\
\text { inside so strong' } \\
\text { by Labi Siffre }\end{array}$ & $\begin{array}{l}\text { Manchester } \\
\text { Community Choir }\end{array}$ & Mixed-sex choir, singing acapella \\
\hline
\end{tabular}


The hour-long broadcasts in 2005, 2015 and 2016 followed a very similar structure, though with additional speakers, more musical items, additional video packages (e.g. following a survivor of Belsen returning to the Camp), and an extended sequence of candle lighting as the penultimate segment before a final song. The national HMD ceremony in Britain should therefore be approached as an example of multi-genre epideictic rhetoric, working up meanings through a hybrid combination of genres (speeches, poems, readings), author/animators and modes (speech, music, light, movement and silence). Below, I examine the sections of the ceremonies that included non-political actors; in a companion article, I analyse the speeches delivered by politicians. My analysis below specifically orientates to the distinction between non-artistic and artistic means of persuasion.

\section{Non-artistic epideictic rhetoric}

Each broadcast programme of the HMD ceremony includes examples of texts that could be, and have been, used in other contexts. These texts - photographs and archival film - are used to demonstrate the facticity of the Holocaust. As Bathrick (2008: 1) put it: media visualizations serve "for some as virtual access to knowledge of the horror; in a few cases, they even provided preeminent verification that it actually happened [...] pictorial icons by which many have sought to capture the seemingly unimaginable.” That is, they are used to document the past - or, as an introduction during the 2016 ceremony put it, to remind us of "the scenes that so shocked the world at the end of the Second World War, and are still shocking us all today” (2016: 2.41-2.48). 
Table 2: Historic narrative, 2016 Ceremony broadcast

\begin{tabular}{|c|c|c|}
\hline$[3.02]$ & 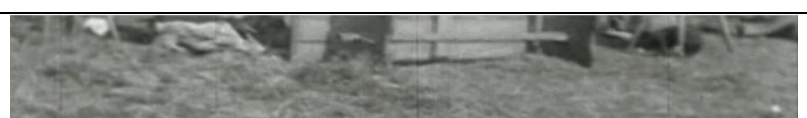 & $\begin{array}{l}\text { [Music plays: duet with } \\
\text { piano and violin] }\end{array}$ \\
\hline \multicolumn{3}{|l|}{ [3.19] } \\
\hline [3.43] & 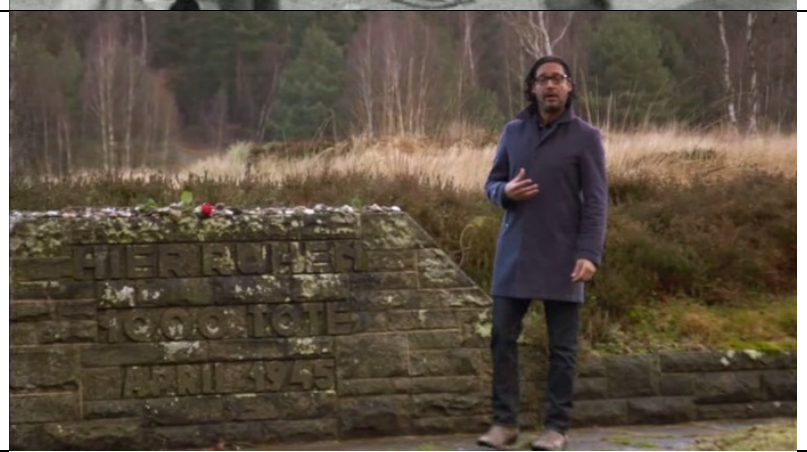 & $\begin{array}{l}\text { [...presenter David } \\
\text { Olusoga] “a camp that had } \\
\text { already become a vast, open } \\
\text { air cemetery. }\end{array}$ \\
\hline [3.48] & 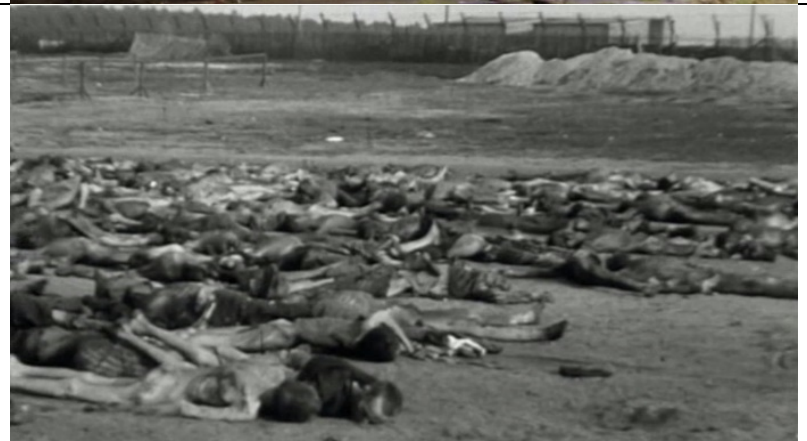 & $\begin{array}{l}\text { [Olusoga, voice over] There } \\
\text { were thousands upon } \\
\text { thousands of bodies. Piled } \\
\text { up, across the camp.” }\end{array}$ \\
\hline
\end{tabular}

The images used in montages such as this - included in similar audio-visual packages in the 2005, 2015 and 2016 ceremonies - are dominated by the now familiar visual black and white iconography of the Holocaust: camps; corpses; barbed wire; emaciated bodies; striped 'pyjama-style' suits; and soldiers. Such film and images are occasionally included without commentary - they are used in the programme opening credits, or as a projected backdrop to 
a speaker on stage, or are intercut with footage of survivor testimony as exemplars of the barbarity they experienced and are describing. When images are referred to directly, they are prefaced by reporting verbs that entail the realist assumptions of the speakers: the film and images demonstrate, show, make evident or, in the case of the montage in Table 2, they "revealed the full scale of Nazi barbarism”.

There is, of course, no question that this is what they do: they document inhumanity and they retain their ability to shock and disgust. However, we do well to remember that these images also have a production history, which is often elided by the way that archival footage from different sources is edited together. Thus, the historic narrative from 2016, presented in Table 2 above, continues as follows:

Table 3: Historic narrative, 2016 Ceremony broadcast

\begin{tabular}{|c|c|c|}
\hline$[4.10]$ & है & $\begin{array}{l}\text { [David Olusoga, voice over] } \\
\text { "Those liberated by the } \\
\text { Allies across Europe, in } \\
\text { 1945, were survivors }\end{array}$ \\
\hline [4.15] & $\frac{1}{2}$ & $\begin{array}{l}\text { of the brutal concentration } \\
\text { and extermination camps, } \\
\text { established throughout Nazi } \\
\text { occupied countries. }\end{array}$ \\
\hline [4.31] & witis & $\begin{array}{l}\text { Barbarous institutions, where } \\
\text { millions of people had been } \\
\text { sent to be worked to death.” }\end{array}$ \\
\hline
\end{tabular}


The three sections of archival film are clearly being used as exemplars of three historic 'scenes’ described in voice over: of survivors; of Nazi camps; and being worked to death. The provenance of the first image is unclear, though it's typical of 'liberator footage' shot at western camps, by British and American cameramen. The second and third scenes, however, are clearly different: they show Nazis (including Heinrich Himmler) brutalising victims, and therefore must have been filmed by Nazi cameramen. We should therefore consider their objective: what these images were originally intended to achieve, and the extent to which the ideology of the filmmaker is implicit in the perspectivisation of the image. This is, after all, 'perpetrator footage', and its existence is simultaneously an index, an icon and a symbol of power abuse; those being dehumanised in the images are meant to be viewed (by us, even now) as less than human. In his examination of perpetrator photographs, Prager (2008: 19) asks "whether one needs to theorize new modes of reading in order to examine" images taken by those responsible for committing the atrocities depicted. Can, or should, we treat the “camera as a metonymic extension of Nazi weaponry” (Prager 2008: 22)? And, when viewing these images, even at HMD ceremonies, “To what extent are we making ourselves complicit with the values [...] of a particular point of view?” (Bathrick 2008: 3). That said, 'liberator' images may also be used as part of fallacious symptomatic visual arguments. Hannah Arendt, for example, examined the way that many of the Allied photos, taken immediately after the war, communicated 'misleading' impressions of the Holocaust: These images mislead us, she contends, because they depict almost exclusively concentration camps located more to the west at a specific moment of chaos and disintegration in the final days of the war and not how the camps functioned for most of the three years before that. By the initial deployment of the photos, the mountains of dead and half-dead bodies in Buchenwald, Dachau and Bergen-Belsen were 
transformed in people's minds into the reality of the camps in toto, although none of them were extermination camps. (Bathrick 2008: 6)

The issue with liberator images, then, is different from that of perpetrator images. With perpetrator images, we cannot assume even a basic "indexical link of the analogue image with the pro-filmic world” (Böser 2012: 38), given that subjects were manipulated, scenes staged and frequently re-shot to create precise filmic tableaus that reflected Nazi ideological preoccupations. $^{2}$ For liberator images, and indeed all images taken of the camps after liberation, the critical issues are less their indexical function, and more the ways that they have taken on iconic or symbolic meanings. Without sufficient clarification and contextualisation, directing the audience how we are to understand the standpoint of the nonartistic proof, they could be used (fallaciously) to symptomatically 'represent Belsen', or even 'the Holocaust' as a whole, rather than the particular pro-filmic scene.

\section{Artistic epideictic rhetoric}

Artistic means of persuasion can be split into two groupings, according to their production format (Goffman 1981). In any communicative event, Goffman (1981: 144) argues that the speaker/writer role can be broken down into three functional roles - the animator, the author and the principal. Taking each in turn, Goffman suggests: the author is realised by "someone who has selected the sentiments that are being expressed and the words in which they are encoded"; the animator is the "body engaged in acoustic activity", or the "individual[s] active in the role of utterance production"; whilst the principal is "someone whose position is established by the words that are spoken, someone whose beliefs have been told, someone who is committed to what the words say" (emphases added, Ibid.). As Table 1 showed, HMD commemorative events include Delivered texts, where the animator reads the words of 
another author; and Embodied texts, where the animator and author are the same person. In both cases, the principal is the norm circle as a whole (Richardson 2017b).

Whilst Delivered texts are a vital part of commemorative events - their use and reuse over time contributing to a de facto commemorative liturgy - it is Embodied texts that I analyse for the remainder of this article.

\section{Embodied texts}

Two forms of Embodied text play a central role in HMD commemoration: survivor testimony and speeches by the Chief Rabbi. Together - the former communicating first-hand historical experience and the latter communicating values - they represent the necessary and sufficient features of the national Holocaust commemoration.

The first segment of the 2002 ceremony involves two unnamed Holocaust survivors recounting fragments of personal narratives of oppression; their collective narrative is added to later in the broadcast, by three further unnamed survivors. ${ }^{3}$ From 2005 , the survivors featured in the broadcasts were always named, identified by on-screen captions: Iby Knill and Otto Deutsch spoke in 2015, also appearing in a video segment with fellow Holocaust survivors Renee Salt and Ivor Perl; Bosnian genocide survivor Kemal Pervanic featured in a second video segment; Gena Turgel read from her memoire of the Holocaust, immediately before the minutes' silence and the ceremonial lighting of candles; and the penultimate segment of the ceremony involved Otto Deutscher, Renee Salt, Iby Knill and Kemal Pervanic recounting “What I hope people will learn”. In the 2016 broadcast, Embodied testimony was given by Holocaust survivors Susan Pollock, Joan Salter and Cirla Lewis, whilst testimony from a survivor of the ongoing genocide in Darfur was Delivered by the actress Naomie Harris. 
One of the more striking instances of Embodied survivor testimony was included in the 2005 ceremony, and spoken by Hannah Goslar. Her inclusion seems designed to provide an emotional jolt - the segment immediately before was a reading from Anne Frank’s Diary, where Anne recounts an upsetting nightmare, in which her friend Hannah died. The camera then cuts to another woman on stage, who states: "I was the girl Hannah Goslar. Anne Frank dreamed about my death and wrote about it in her diary. But it was she who died while I survived”. Opening her speech with the words "I was the girl Hannah Goslar”, as opposed to simply "I am Hannah Goslar” is a very interesting choice. In one sense, speaking of Hannah Goslar in the past tense is literally true: since emigrating to Israel in 1947, and marrying Walter Pick, she now goes by the name of Hanneli Pick-Goslar. However, the choice of words also speaks to the profound differences between her life before, during and after the war. The war changed her; the Holocaust changed her; she no longer considers herself to be the same person.

Pernot (2015: 83) points out that archetypical “epideictic orators are distinguished persons: distinguished as much by their wisdom and honesty as through their culture and social and political position.” With Hannah Goslar we have an exemplary example: someone who can speak, with authority, on the personal qualities of Anne Frank - described by Cole (2000: 46) as "the ideal symbol of the 'innocent victim' and the ideal symbol of potential snuffed out”because, as Hannah put it in her speech, "she was my childhood friend". As she speaks to the audience, images of times she shared with Anne when she was young can be seen projected on the screen behind her; for the televisual audience, these are shown as full-screen images, which the camera slowly and deliberately zooms into. 
Table 4: Multimodality in Hannah Goslar's speech, 2005

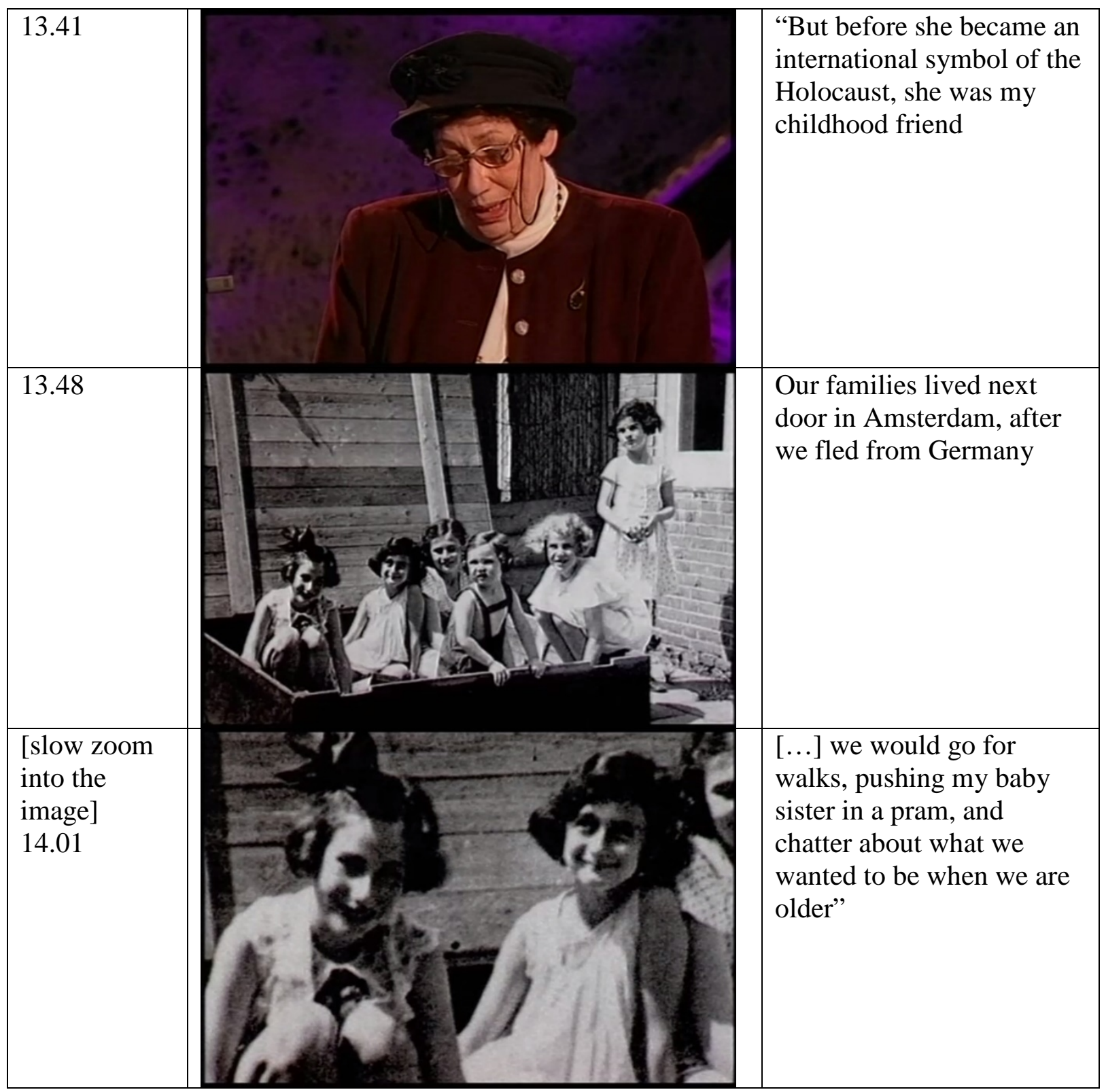

Table 5: Multimodality in Hannah Goslar’s speech, 2005

15.24


The power of this multi-modal testimony comes from the combination of the commonplace and the exceptional: a photo of smiling children, enjoying their time together in the sun; children playing together, imagining what they wanted to be when they got older; and the awful truth that Anne Frank, the smiling girl we see on screen, was murdered; she, and more than a million like her, never grew to be adult. These photographic documents are therefore not merely non-artistic rhetorical proofs of the claim that Hannah knew, and was close with, Anne; they function as icons (in the Peircean sense) of Jewish life in Europe before the war, as symbols of what was lost - and therefore also as symptomatic demonstrations of the inhumanity of Nazism.

Hannah Goslar's testimony is striking for another reason - there are only three jokes told during all four televised HMD commemorations (3.5 hours of television), and two of these are told by Hannah. The second of these, that when she was young she swapped a picture card of the-then Princess Elizabeth for a different member of European Royalty, raised a wry smile from HRH Queen Elizabeth II, sat in the attending audience:

Figure 1: Smiles in the audience, 2005

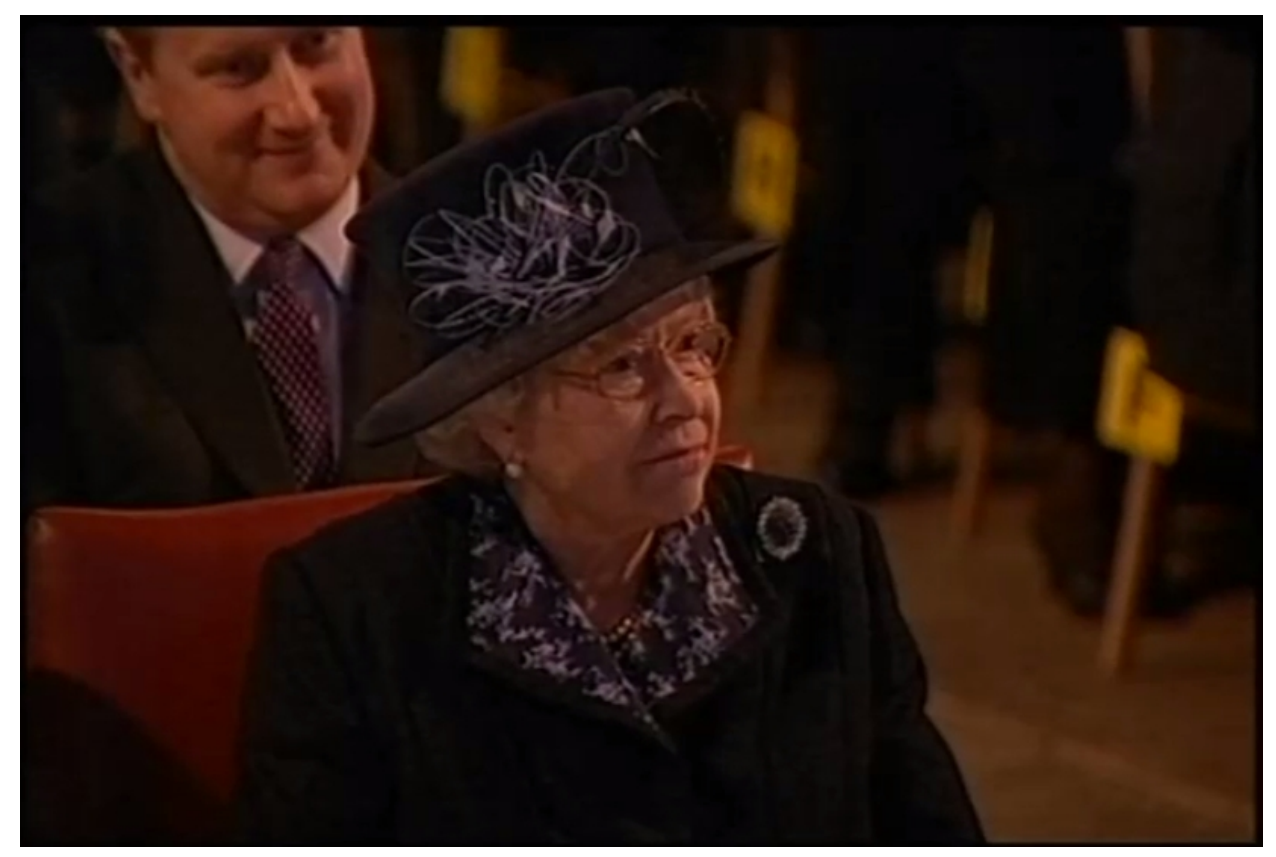

Her first joke is reproduced below: 
[14.09] Anne, of course, wanted to be a writer. My mother used to say about Anne:

'God knows everything. But Anne knows everything better'.

[14.22 - smattering of laughter in audience]

Telling a joke at a Holocaust commemoration, or 'about' a Holocaust victim, is quite an audacious thing to do. ${ }^{4}$ Even summarising it - for example 'Hannah told a joke about Anne Frank' - feels transgressive. The rhetorical success of this joke was due to two factors. First, her ethetic strategies: she reveals practical wisdom of that which she speaks (phronēsis), having suffered through and survived the Holocaust herself; and she demonstrates her virtue (aretē) and good will (eunoia) through the depth of affection she evidently still holds for Anne. Second, the joke works because of what it reveals about Anne's character; evidently, she was, in colloquial terms, a bit of a 'clever clogs', whose belief that she 'knows best' was lampooned by Hannah’s Mother. The joke works because it helps rescue Anne from her iconic status as innocent "symbol of the Holocaust”; it restores some of her complexity, reminds us of other similarly self-assured children (and how impossible they are to reason with!), and reveals something rich and poignant about Anne’s interactions with friends and family.

The Chief Rabbi has given a speech at every national HMD commemoration in Britain since its inception (both those televised and those not). In 2002 and 2005 these speeches were given by then-Chief Rabbi Jonathan Sacks; in 2015 and 2016, the current Chief Rabbi Ephraim Mirvis spoke. The structure and length of the speech delivered at the 2002 ceremony mean it is particularly suitable for analysis; it is reproduced in its entirety below:

[11.08] When humans beings do good, said the sages, they're little lower than the angels. But when they do evil, they sink lower than the beasts. And in the Holocaust, humanity reached its deepest abyss. Whole communities who had lived with their neighbours for a thousand years, were murdered in days. A guard at Auschwitz, 
testifying at the Nuremberg trial, admitted that at the height of the genocide, when the camps were killing ten thousand Jews a day, children were thrown into the furnaces alive.

\section{[11.58 music starts to fade in]}

The Holocaust was a black hole in history. It was evil for evil's sake.

And as we think of those who didn't escape. What would they want of us now? Those who managed to leave a final message, asked just one thing: that we remember. That we remember what happens when hate takes hold; when evil is done and no one protests; when we forget that that life is sacred, and strangers, too, are human. Create, they would have said, a better world, where doors are open to those in danger of their lives. Where we respect the dignity of difference, and where our shared humanity gives us the courage to fight, for those who cry for help. Let us teach these things, diligently, to our children.

[speech ends 13.05; music ends 13.15]

The speech adopts a two-part structure: the first half, a Judicial argument, looks back to the past and presents an argument regarding the inhumanity and injustice of the Holocaust. The argument scheme of this half of the speech is relatively straightforward: he presents two standpoints, each supported by symptomatic illustrations - one supported by compound illustrations, and the second supported by a single example. This can be presented schematically as in the figure below: 
Figure 2: Reconstruction of Sacks’ Forensic argument

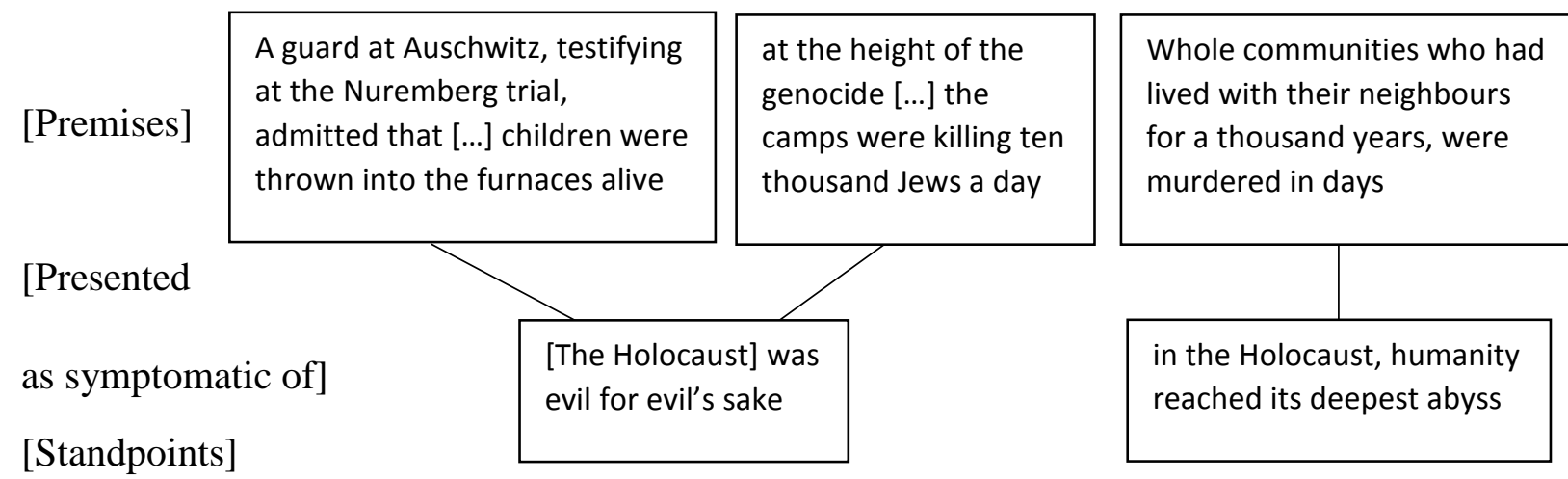

It is notable that, whilst the stress of this first half of the speech is on the genocide of Europe’s Jews, the identity and motivation of the killers are vague: they are simply "evil” murderers. And whilst Auschwitz and "the camps" are mentioned, nothing else is said about the circumstances of these murders, nor about the circa 3million murdered Jews who were not killed in camps. Some scholars - for example Bloxham (2002) - have criticised official HMD commemoration on the grounds that it tends to offer only broad accounts of both the motivations of perpetrators and the historic contexts that variously enabled and obstructed their actions. However, such criticism misunderstands the rhetorical conventions of commemorative discourse. Just as it would be inappropriate for a funeral orator to relay the precise manner of someone's death in graphic detail, so too it could be undignified for Holocaust commemoration to "dwell on concrete descriptions of the specific actions taken by” perpetrators (Condit 1985: 294). Echoing precisely Condit’s (1985) analysis of the Boston Massacre Orations, here the Chief Rabbi doesn't provide the audience with “newspaper-like reportorial accounts”, but instead “depicted events on a larger canvas” (p.294). He offered an "abstract, yet passionate” account of the Shoah - referring to the mass murder of children, in particular, and by the most callous means - as a way of placing the genocide "in the emotional and valuational contexts of the community" (p.296). In so doing, 
he emphasises the (im)moral dimensions of Holocaust - as “evil” - and the values of the norm circle, rather than broaching "the questions most important to historians of the Holocaust: Who carried out the attacks on Jews and other targets, on their property, their communities, their dignity, their lives?” (Bergen 2012: 160).

In the second half of the speech, Sacks presents two deliberative arguments: that we should "remember”, and that we should create "a better world”. Each of these standpoints is supported by arguments from causation, presented as two lists of three (tricolon) - though Sacks also argues that we should remember the past because the victims of the Holocaust have apparently asked it of us (which is a version of an argumentum ad vericundium). It is notable that the musical accompaniment fades in as he starts to deliver this deliberative case the swell of the music complimenting the emotional tenor of the speech and his hopes for "a better world" where "we respect the dignity of difference”. In Table 6, below, I first provide a reconstruction of the argumentation and its unexpressed premises:

Table 6: Reconstruction of Sacks’ deliberative arguments, 2002

\begin{tabular}{|c|c|c|}
\hline [Standpoints] & $\begin{array}{l}\text { [victims asked us to remember] } \\
\text { [acting in accordance with } \\
\text { wishes of Holocaust victims is } \\
\text { a way to honour them] } \\
\text { [the past provides an example } \\
\text { of how not to act in the face of } \\
\text { hate and evil] } \\
\text { [this knowledge will help us to } \\
\text { face evil in the future] }\end{array}$ & $\begin{array}{l}\text { [we need to remember our shared } \\
\text { humanity] } \\
\text { [humanity, in all its difference, is of } \\
\text { equal worth; we should respect } \\
\text { difference] } \\
\text { [we should help those in danger of their } \\
\text { lives by opening our doors to them] } \\
\text { [we should help those who cry out for } \\
\text { help] } \\
\text { [these would be achieved in/through } \\
\text { creating a better world] } \\
\text { [Therefore] } \\
\text { [We should] "Create [...] a better world” }\end{array}$ \\
\hline
\end{tabular}


Sacks argues that politically advantageous social conditions will be brought about - caused by remembering. Remembering and forgetting, presuppose both a remembering/forgetting subject and the existence of knowledge that this subject is remembering/forgetting. In one list of three, starting “That we remember...”, Sacks links processes of remembering/forgetting to moral action in a causal way - that is, we should remember past injustices to ensure an advantageous, worthy and just future. This tricolon simultaneously communicates: grammatical entailments that we know something (and must remember rather than forget); more specific presuppositions that are inferable from the immediate context of the speech situation (a HMD speech, given by the Chief Rabbi, inferring that this is knowledge related to the Holocaust); moral presuppositions about our values, structured as ‘if/then’ conditionals; and a consequent application of these to support an entailed moral action. Taking each clause in turn, we can reconstruct their argumentation as follows:

“That we remember what happens when hate takes hold” [entailment] we have knowledge of what happens when hate takes hold; [context-invoked implication] the Holocaust is what happens when hate takes hold; [conditional] if we are to avoid another Holocaust then we need to ensure hate doesn't take hold

[corollary: deliberative case for moral action] we should ensure hate doesn't take hold [That we remember what happens] "when evil is done and no one protests" [entailment] we have knowledge of what happens when evil is done and no one protests;

[context-invoked implication] the Holocaust happens when evil is done and no one protests; 
[conditional] if we are to avoid another Holocaust then we need to protest when evil is done]

[corollary: deliberative case for moral action] we should protest against evil

[That we remember what happens] "when we forget that that life is sacred, and strangers, too, are human.”

[entailments] we have knowledge that life is sacred; we have knowledge that the lives of strangers are also sacred;

[context-invoked implications] we know what happens when we forget life is sacred (x); we know what happens when we forget the lives of strangers are also sacred (y); the Holocaust happens when (x) and (y);

[conditional] if we are to avoid another Holocaust then we need to remember that life (including the lives of strangers) is sacred

[implication] if life (including that of strangers) is sacred then it should be protected; [corollary: deliberative case for moral action] we should protect life, including the lives of strangers

Taken together, these three deliberative cases for moral action - we should ensure hate doesn't take hold; we should protest against evil; we should protect life - could be viewed as obvious. Indeed, in many ways the case for action is the corollary of the terms employed, given their overwhelmingly negative prosody - of course hate should be opposed (who would argue that hate needs to be nurtured?). Is advancing these standpoints, therefore, a pointless exercise? No, as Pernot (2015: 96) points out, the answer is subtler. Granted that listeners already know their duty, the oration serves the useful purpose of a reminder, especially at times when hearers might be tempted to forget. Even granting that listeners always act as they should, the orations still strengthen their resolve, encourage them to persevere, and urge them to go further. 
The seeming banality of the argumentation also belies its national context-specific nature. This meta-narrative account - that the Holocaust is an example of prejudice in extremis, and that we can guard against future atrocities by keeping the prejudice of others in check - are 'lessons' which liberal multi-ethnic bystander countries take from the Holocaust; they are the 'lessons' that pervade British and American commemoration, in particular, because to argue that the Holocaust took place because of the prejudice of others is in no way threatening to the national self-image. However, they are absent from the commemoration of perpetrator countries like Germany, which has historically tended towards a more functionalist explanation of the Holocaust. Similarly, they are absent from Israeli commemorative discourse, where historically the Holocaust has been viewed as the ultimate proof of both Europe's indefatigable antisemitism and the corresponding need of a solution, in the form of Israel (Marrus 2015).

I point this out not to suggest that I think one or other of these lessons is correct. But rather to note that the moral lessons taken from Holocaust relate to time and place. They tend to present themselves as universal - in the case of the Chief Rabbi's speech, as our presupposed knowledge that we need to remember - however they are particular, and particular in ways that index the norm circle that produces, consumes and shares them.

\section{Conclusion}

This article explored the rhetoric, and mass-mediation, of the national Holocaust Memorial Day (HMD) commemoration ceremony, as broadcast on British television. I argued that these commemorative events represent a blended rhetorical genre that bring together the forensic and epideictic species of rhetorical argument, detailing the circumstances and injustices of the Holocaust in order to revivify our commitment to the values that it so clearly transgressed. However, given that Nazi guilt is taken to be axiomatic, the primary rhetorical goal of these 
commemorative ceremonies is epideictic rather than forensic. The purpose of epideictic rhetoric is not simply "to say the truth, but to re-affirm and recreate afresh the consensus around prevailing values” (Pernot 2015: 98) and, as such, epideictic speeches are one way in which a norm circle is discursively invoked, shaped and refreshed.

The national ceremony commemorating Holocaust Memorial Day has been broadcast four times since the first HMD in 2001. These programmes function as a complex, multi-modal epideictic, recounting the injustice of genocide in order to revivify shared social values. They feature a combination of images, film clips, music, candle lighting and readings and speeches made by survivors and other public figures, each of which can be treated as a rhetorical text which contributes to the epideictic whole. As one of three species of rhetoric, epideictic relies on a combination of non-artistic and artistic means of persuasion. Just as such means of persuasion can be used reasonably, so too can both derail into fallacy by, for example, presenting an image that is not symptomatic of that which it claims, or by presenting an overly reductive narrative of the Holocaust as caused by prejudiced ideas.

\section{Acknowledgement}

This research was funded by a Leverhulme Trust Research Fellowship. I gratefully acknowledge this support

\section{References}

Allwork, L. (2015). Holocaust Remembrance between the National and the Transnational: The Stockholm International Forum and the First Decade of the International Task Force. London: Bloomsbury Academic. 
Aristotle (2007). On Rhetoric: A Theory of Civic Discourse (Translated with Introduction, Notes, and Appendices by George A. Kennedy, $2^{\text {nd }}$ Edition). New York \& Oxford: Oxford University Press

Bathrick, D. (2008). Introduction: Seeing against the Grain: Re-visualizing the Holocaust. In Bathrick, D., Prager, B. \& Richardson, M.D. (eds) Visualizing the Holocaust: Documents, Aesthetics, Memory (pp.1-18). Rochester, NY: Camden House. Bergen, D.L. (2012). Studying the Holocaust: Is Commemoration History? In Stone, D. (ed) The Holocaust and Historical Methodology (pp.158-177). New York/London: Berghahn.

Billig, M. \& Marinho, C. (2017). The Politics and Rhetoric of Commemoration: How the Portuguese Parliament Celebrates the 1974 Revolution. London/New York: Bloomsbury Academic.

Böser, U. (2012). "A Film Unfinished": Yael Hersonski's Re-representation of Archival Footage from the Warsaw Ghetto. Film Criticism, Vol. 37, No. 2 (Winter, 2012-13) 38-56.

Bloxham, D. (2002). “Britain’s Holocaust Memorial Days: Reshaping the past in the service of the present”. Immigrants \& Minorities, vol. 21 no. 1-2, 41-62.

Burgess, T. C. (1902). Epideictic literature. Chicago: University of Chicago Press.

Butler, J. (1995). "Conscience Doth Make Subjects of Us All". Yale French Studies, No. 88, Depositions: Althusser, Balibar, Macherey, and the Labor of Reading (1995), 6-26.

Cesarani, D. (2000). Seizing the Day: Why Britain Will Benefit from Holocaust Memorial Day. Patterns of Prejudice, 34(4), 61-66.

Cesarani, D. (2001). Does the Singularity of the Holocaust make it Incomparable and Inoperative for Commemorating, Studying and Preventing Genocide? Britain’s 
Holocaust Memorial Day as a Case Study. The Journal of Holocaust Education, 10:2, 40-56.

Cole, T. (2000). Selling the Holocaust: From Auschwitz to Schindler, How History is bought, packaged and sold. New York: Routledge.

Condit, C. M. (1985). The Functions of Epideictic: The Boston Massacre Orations as Exemplar. Communication Quarterly, 33(4), 284-299.

Duffy, B. K. (1983). The Platonic functions of epideictic rhetoric. Philosophy \& Rhetoric, 16(2), 79-93.

Elder-Vass, D. (2010). The Causal Power of Social Structures. Cambridge: Cambridge UP.

Elder-Vass, D. (2011). The Causal Power of Discourse. Journal for the Theory of Social Behaviour 41(2), 143-160.

Elder-Vass, D. (2012). The Reality of Social Construction. Cambridge: Cambridge UP.

Elder-Vass, D. (2015). Collective Intentionality and Causal Powers. Journal of Social Ontology 1(2), 251-269.

Forchtner, B. (2016). Lessons from the Past? Memory, Narrativity and Subjectivity. London: Palgrave.

Goffman, E. (1981). Forms of Talk. Philadelphia, PA: University of Pennsylvania Press.

Groarke, L. (2013). The Elements of Argument: Six Steps to a Thick Theory. In Kišiček, G.

\& Žagar, I. Ž. (eds.) What Do We Know about the World? Rhetorical and argumentative perspectives (pp.25-44). Ljubljana: Educational Research Institute.

Gutman, Y., Brown, A.D. \& Sodaro, A. (eds.) (2010). Memory and the Future: Transnational Politics, Ethics and Society. New York: Palgrave Macmillan.

Hauser, G. A. (1999). Aristotle on epideictic: The formation of public morality. Rhetoric Society Quarterly, 29:1, 5-23. 
Heer, H., Manoschek, W., Pollak, A. \& Wodak, R. (eds.) (2008). The Discursive Construction of History: Remembering the Wehrmacht's War of Annihilation. Houndmills: Palgrave.

Hyde, M. J. (2005a). Acknowledgment, conscience, rhetoric and teaching: The case of Tuesdays with Morrie. Rhetoric Society Quarterly 35(2), 23-46.

Hyde, M. J. (2005b). The rhetor as hero and the pursuit of truth: The case of 9/11. Rhetoric \& Public Affairs, 8(1), 1-30.

Kampf, Z \& Katriel T. (2016). Political Condemnations: Public Speech Acts and the Moralization of Discourse. In Carbaugh, D. (ed.) The Handbook of Communication in Cross-Cultural Perspective. New York: Routledge.

Kansteiner, W. (2002). Finding Meaning in Memory: A Methodological Critique of Collective Memory Studies. History and Theory 41(2), 179-197.

Kansteiner, W. (2006). In Pursuit of German Memory: History, Television, and Politics after Auschwitz. Athens: Ohio University Press.

Kansteiner, W. (2008). Sold Globally - Remembered Locally: Holocaust Cinema and the Construction of Collective Identities in Europe and the US. In Berger, S., Eriksonas, L. \& Mycock, A. (eds) Narrating the Nation: Representations in History, Media and the Arts (pp.153-180). New York \& Oxford: Berghahn Books.

Kennedy, G.A. (2005). Introduction. In Aristotle (2007) On Rhetoric: A Theory of Civic Discourse (Translated with Introduction, Notes, and Appendices by G. A. Kennedy, $2^{\text {nd }}$ Edition) (pp.1-25). New York \& Oxford: Oxford University Press.

Krzyżanowski, M. (2010). The Discursive Construction of European Identities: A Multilevel Approach to Discourse and Identity in the Transforming European Union. Frankfurt am Main: Peter Lang.

Lauer, I. (2015). Epideictic Rhetoric. Communication Research Trends 34(2), 4-18. 
Macdonald, S. (2005). Commemorating the Holocaust: Reconfiguring National Identity in the Twenty-First Century. In Littler, J \& Naidoo, R. (eds) The Politics of Heritage: The Legacies of 'Race’ (pp.49-68). Oxon: Routledge.

Marrus, M.R. (2015). Lessons of the Holocaust. Toronto: University of Toronto Press.

Meyers, O., Zandberg, E. \& Neiger, M. (2014). Communicating Awe: Media Memory and Holocaust Commemoration. Houndmills: Palgrave.

Pearce, A. (2013). Britain’s Holocaust Memorial Day: Inculcating ‘British’ or ‘European’ Holocaust Consciousness? In Sharples, C. \& Jensen, O. (eds.) Britain and the Holocaust Remembering and Representing War and Genocide (pp.190-211). Houndmills: Palgrave.

Pearce, A. (2014). Holocaust consciousness in contemporary Britain. London: Routledge. Perelman, Ch., \& Olbrechts-Tyteca, L. (1969). The New Rhetoric. A Treatise on Argumentation. Notre Dame, IN: University of Notre Dame Press.

Perelman, Ch. (1982). The Realm of Rhetoric. Notre Dame, IN: University of Notre Dame Press.

Pernot, L. (2015). Epideictic Rhetoric: Questioning the Stakes of Ancient Praise. Austin TX: University of Texas Press.

Prager, B. (2008). On the Liberation of Perpetrator Photographs in Holocaust Narratives. In Bathrick, D., Prager, B. \& Richardson, M.D. (eds) Visualizing the Holocaust: Documents, Aesthetics, Memory (pp.19-37). Rochester, NY: Camden House.

Prager, B. (2014). The Warsaw Ghetto, Seen from the Screening Room: The Images That Dominate ‘A Film Unfinished’. New German Critique, 41(3), 135-157.

Reisigl, M. (2018). The Discourse-Historical Approach. In Flowerdew, J. \& Richardson, J.E. (eds.) The Routledge Handbook of Critical Discourse Studies (pp.44-59). London/New York: Routledge. 
Reisigl, M. \& Wodak, R. (2001). Discourse and Discrimination. London: Routledge.

Reisigl, M. \& Wodak, R. (2009). The Discourse-Historical Approach. In Wodak, R., and Meyer, M. (eds.) Methods of Critical Discourse Analysis (pp. 87-121). London: Sage. Richardson, J.E. (2007). Analysing Newspapers: An approach from Critical Discourse Analysis. Houndmills: Palgrave.

Richardson, J.E. (2017a). British Fascism: A Discourse-Historical Analysis. Stuttgart: ibidem Verlag.

Richardson, J.E. (2017b). Making memory makers: Interpellation, norm circles and Holocaust Memorial Day Trust workshops. Memory Studies iFirst 1-18.

Richardson, J.E. \& Wodak, R. (2009). Recontextualising fascist ideologies of the past: rightwing discourses on employment and nativism in Austria and the United Kingdom. Critical Discourse Studies, 6(4), 251-267.

Rosenfield, L. (1980). The practical celebration of epideictic. In White, E. E. (ed.) Rhetoric in transition: Studies in the nature and uses of rhetoric (pp. 131-155). State College, PA: The Pennsylvania State University Press.

Sauer, C. (2012). Multimodality and performance: Britain’s first Holocaust Memorial Day. In Berlin, L.N. \& Fetzer, A. (eds) Dialogue in Politics (pp.241-307). Amsterdam: John Benjamins.

Shandler, J. (1999). While America Watches: Televising the Holocaust. Oxford: Oxford University Press.

Slavíčková, T. (2013). The rhetoric of remembrance: Presidential Memorial Day speeches. Discourse \& Society 24(3), 361-379.

Slavíčková, T. (2014). Oratorical Style and Performance in the Epideictic Speeches Of American Presidents. Brno Studies in English 40(1), 227-241. 
Stone, D. (2013). The Holocaust, Fascism and Memory: Essays in the History of Ideas.

Houndmills: Palgrave.

Tileagă, C. (2011). (Re)writing biography: Memory, identity, and textually mediated reality in coming to terms with the past. Culture \& Psychology, 17(2), 197-215.

Vatnoey, E. (2015). Leaders’ Response to Terrorism: The Role of Epideictic Rhetoric in Deliberative Democracies. Journal of Public Deliberation: Vol. 11: Iss. 2, Article 5. Available at: http://www.publicdeliberation.net/jpd/vol11/iss2/art5.

Wertsch, J.V. (2002). Voices of Collective Remembering. Cambridge: Cambridge University Press.

Whyborn, C. (2011). What difference can a day make? In Andrews, M. Bagot Jewitt, C. \& Hunt, N. (eds) Lest We Forget: Remembrance and Commemoration (pp.56-59). Stroud, Gloucester: The History Press.

Wodak, R. \& De Cillia, R. (2007). Commemorating the past: the discursive construction of official narratives about the 'Rebirth of the Second Austrian Republic'. Discourse \& Communication, 1(3), 337-363.

Wodak, R., de Cillia, R., Reisigl, M. \& Liebhart, K. (1999). The Discursive Construction of National Identity. Edinburgh: Edinburgh University Press.

\footnotetext{
${ }^{1}$ Resolution adopted by the General Assembly on the Holocaust Remembrance (A/RES/60/7, 1 November 2005), http://www.un.org/en/holocaustremembrance/docs/res607.shtml [accessed 04 September 2017] ${ }^{2}$ See, for example, Böser's (2012) and Prager's (2014) analysis of Yael Hersonski's documentary "A Film Unfinished", examining reels of film shot by Nazis in the Warsaw ghetto.

${ }^{3}$ An official programme is produced for all national HMD ceremonies, detailing the running order and speakers. The speakers would therefore not be anonymous for those attending the ceremony in the Hall, only for those watching the television broadcast.

${ }^{4}$ The third and final joke in the corpus, also from the 2005 ceremony, was told by the writer and television presenter Stephen Fry; it failed to generate any laughter.
} 